УДК $784-057.87$

DOI:

Петро Турянський, доцент кафедри народних музичних інструментів та вокалу Андрій Боженський, старший викладач кафедри народних музичних інструментів та вокалу Інституту музичного мистеитва

Дрогобицького державного педагогічного університету імені Івана Франка

\title{
ЗНАЧЕННЯ НАВЧАЛЬНОГО МАТЕРІАЛУ У ІНДИВІДУАЛЬНІЙ ВОКАЛЬНІЙ ПІДГОТОВЦІ СТУДЕНТА
}

У статті висвітлено значення навчального матеріалу в індивідальній підготовці студента, надано великого значення добору вокальних творів, які сприятимуть розвитку вокально-технічних даних студента, спрямовують його на осягнення вокальних навиків та вокально-педагогічного репетуару.

Правильний репертуарний режим студента-співака $і$ загальне прогнозування творчих перспектив вказують напрям розвитку його вокально-технічних і художньо-виконавських даних.

Зазначено, щзо народна пісня у вихованні студента відіграє велику роль, очищає дух, дарує зразки найвищого смаку, зображсальності, майстерності, тому необхідна у репертуарі студента, як матеріал що має величезний ідейно-естетичний та етико-моральний вплив.

Ключові слова: вокальний матеріал, виховний характер, індивідуальний підхід, икільний репертуар, народна пісня.

Jim. 5.

Petro Turyanskiy, Associate Professor of the Folk Musical Instruments and Vocals Department Andriy Bozhenskiy, Senior Lecturer of the Folk Musical Instruments and Vocal Department Institute of Musical Art Drohobych Ivan Franko State Pedagogical University

\section{THE IMPORTANCE OF AN EDUCATION MATERIAL OF THE INDIVIDUAL TRAINING OF STUDENTS}

The correct repertoire of the student-singer and the general forecasting of the creative perspectives indicate the direction of the development of vocal and technic skills and artistic and performance data.

The article states that the folk song in the education of the student plays an important role, purifies the spirit, gives samples of the highest taste, image and skill. That's why, it is necessary to use it in the student's repertoire as a material which has a huge ideological and aesthetic, ethical and moral value. The convenience of repertoire selection is connected with the folk song. In this regard, the teachers of solo singing carry out a lot of work to select the appropriate vocal material which is compiled and published as a teaching manual and it also contains simple works, songs and romances of prominent Ukrainian composers, such as M. Lysenko, S. Lyudkevych, D Sichinskiy, A. Kos-Anatolskiy and works of O. Bilash, P. Mayboroda, V. Nadenenko, B. Filts, O. Zadora, V. Zaremba and others.

The article provides tips for teachers of musical art and shows how to disclose in a professional way the grandeur and beauty of the Ukrainian song - one of the greatest wealth of our people. A significant place in the article is dedicated to the folk song, which is a gracious material for producing free cantilena, soft sound of the voice in a sufficiently wide range without upper and lower extreme notes because folklore works are characterized by flexible melodic lines, so they are useful while working at the evenness and ease of sound leading.

Keywords: vocal material, an education character, an individual approach, school repertoire, a folk song.

П остановка проблеми. На сучасному етапі постає потреба у вихованні духовно багатої особистості формування у неї художнього світогляду, засад творчої педагогічної самореалізації.

Із багаторічного досвіду роботи викладачем вокалу у вузі та підготовці студентів до практичної роботи у загальноосвітній школі можна виокреслити низку проблем: перш за все слабкі вокально-природні дані у студентів, зокрема, вокальний слух, загальний інтелект, інструментальну підготовку. Варто акцентувати

(C) П. Турянський,

А. Боженський, 2018 увагу й на недостатню кількість годин на вокальну підготовку студентів, а саме вдосконалення вокально-технічних даних студента.

Мета статті. Виокреслити значимість вокального матеріалу, що впливає на розвиток вокально-технічних здібностей студента та його музично-естетичний розвиток.

Виклад основного матеріалу. Вокальний матеріал має особливе значення у вирішенні всіх основних завдань навчально-виховного процесу при підготовці студента до роботи у 


\section{ЗНАЧЕННЯ НАВЧАЛЬНОГО МАТЕРІАЛУ У ІНДИВІДУАЛЬНІЙ ВОКАЛЬНІЙ ПІДГОТОВЦІ СТУДЕНТА}

загальноосвітній школі. За допомогою заданого матеріалу розвиваються музично-естетичні смаки студента, його творчі здібності, виховуються вокально-технічні та художні навики, бо, як відомо, окремі види навчального матеріалу впливають неоднаково на художнє і технічне виховання студента. Роль вокальних вправ та вокалізів обмежена у розвитку вокальної техніки. I тільки вплив художніх вокальних творів 3 текстом охоплює всі сторони навчального процесу при навчанні співу. Тому у вокальній підготовці вправи та вокалізи розглядаються як допоміжний матеріал для оволодіння художніми творами 3 текстом. Студент-вокаліст розвивається як музикант i виконавець перш за все при правильному підборі репертуару. Ефективність впливу вокального репертуару залежить від відповідної цілі загально-дидактичним і вокальнотехнічним принципам навчання. 3 усіх цих принципів слід виділити: виховний характер, доступність, систематичність і свідомість студента, індивідуальний підхід до нього, єдиний художній і вокально-технічний розвиток співака. Крім вокальних творів для оволодіння вокальною технікою і виконавськими навиками необхідно підкреслити і другу сторону,органічно зв'язану 3 першою: це виховний розвиток вокальних творів в самому широкому розумінні, це ідейна направленість при підготовці майбутнього вчителя, виховання його морально-естетичних якостей. Вони повинні здійснюватись на всіх ланках навчально-виховного процесу і бути максимально усиленні, особливо в класах (солоспіву) індивідуального навчання. В цьому відношенні клас вокалу має хороші можливості. Вокальні твори на відміну від інструментального навчання органічно пов'язані зі словом, несуть конкретно-смисловий зміст і внаслідок цього значно зростають виховні можливості творів. В зв'язку з тим, що художній зміст вокального твору при навчанні сольного співу обумовлює розвиток музично-естетичного смаку студента, важливою якістю навчального репертуару являється його художньо-естетична цінність. Від цієї якості залежить перш за все інтерес студента до освоєння репертуару.

Художній репертуар впливає і на посилення у студента свідомого підходу до навчання, оскільки в кожному новому творі міняються завдання виконання, що сприяють свідомому застосуванні навиків. В умовах стислого курсу сольного співу за період навчання студент встигає освоїти обмежену кількість творів, томупідбір репертуару 3 розрахунком художніх якостей повинен проводитись особливо чітко. Для єдиного художнього і вокально-технічного розвитку студента важливо при підборі репертуару орієнтуватись на голосові дані, на технічну підготовку студента, а також на музично-художню цінність творів, не підбирати твори, які не відповідають одній $з$ цих вимог [3, 70 - 74].

Питання вокально-технічної підготовки репертуару дуже широке, тут не має можливості висвітлити абсолютно всі положення, так як це 3 однієї сторони справа методики, а 3 другої один і той же викладач використовує інші прийоми, враховуючи індивідуальні особливості кожного студента. Хочеться вказати на необхідність дуже клопіткої роботи над виконавчим репертуаром 3 огляду його вокально-технічної підготовки, оскільки дуже важливо привити молодим виконавцям вимогливість до себе і привчити їх до самостійної роботи над своїм репертуаром $[1,97]$.

Матеріалом для підготовки певного періоду роботи можуть бути: окремі протяжні ноти на зручній для студента висоті в три - i п’ятиступеневій послідовності діатонічної гами, найлегші вокалізи і такий самий пісенний репертуар, який би відзначався привабливою розспівністю. При виконанні заданого матеріалу слід віддавати перевагу повільним і помірним темпам, щоб студент міг стежити за якістю звучання голосу. Можливі ускладнення навчального матеріалу, а також виконання його у прискорених темпах - це подальший етап роботи. На цих заняттях необхідно розвивати здатність студента до вироблення інтонаційних барв відповідно до того або іншого психологічного стану. 3 цією метою слід добирати певні твори і навіть окремі фрази із творів $[2,66]$.

В роботі над репертуаром в процесі вивчення творів велике значення, як вокально-технічний прийом має так зване свідоме вспівування. Тут треба зробити особливий акцент на свідомому факторі співу, щоб вспівування було небезцільним багаторазовим повторенням одного і того ж музичного матеріалу, а цілком свідомим засвоєнням музики твору, при цьому виконавцю необхідно добиватися з кожним разом все більшої шліфовки, як загальної вокальної лінії, так і необхідних інтонаційних і мовних нюансів фразування. В повільному темпі потрібно завжди старатися не порушувати загальної концепції твору. Окрім вивчення тексту і мелодії напам'ять також вимагати, щоб голос співака все більше i більше органічно зливався з його музичними інтонаціями, при цьому вчити твір потрібно більше на слух, ніж голосом, а вспівувати потрібно повним голосом. Таким чином, вивчаючи індивідуальні особливості і ступінь вокально- 


\section{ЗНАЧЕННЯ НАВЧАЛЬНОГО МАТЕРІАЛУ У ІНДИВІДУАЛЬНІЙ ВОКАЛЬНІЙ ПІДГОТОВЦІ СТУДЕНТА}

технічної підготовки студента, викладач співу повинен поставити перед ним одну загальну мету навчання і підпорядкувати їй, як все виховання, так і окремі завдання, які виникають на кожному уроці. В залежності від цієї основної мети слід уважно підбирати необхідний навчальний матеріал (гами, вправи, вокалізи, вокально-педагогічний репертуар), який би всебічно урізноманітнив його відповідно до поставленого завдання на кожному даному етапі навчання, перетворивши тим самим акт формування і постановки голосу співака в творчий процес $[1,50]$.

Вивчаючи нові твори можна не на повний голос, а робочим звуком, напівголосно, на повному диханні. Крайні ноти зовсім не потрібно брати повним голосом, поки студент не буде добре знати мелодію всього твору. Приступаючи до виявлення твору, слід дізнатись, хто автор слів, музики, коли написано твір, яка епоха в ньому змальовується, які події оспівуються, які почуття висловлюються.

До того, як акомпаніатор програє кілька разів вокальний твір, студент повинен повторити мелодію частинами, дотримуючись усіх вимог композитора. Кожна нота, якої б тривалості вона не була, має бути проспівана точно і ритмічно. Таким чином, виконавець наближається до розуміння твору і його правильного виконання.

Праця - єдиний шлях, по якому йому треба іти, а енергія, воля і дисципліна - джерела, з яких виконавець черпає свою майстерність. Успіх у вокальному мистецтві нерозривно пов'язаний 3 загальною культурою співака, громадською активністю, трудовою дисципліною, гідним поводженням у колективі, побуті, особистому житті. Виконання вокального твору тільки тоді $€$ переконливим, коли співак зможе розкрити органічно пов'язану між собою творчість двох авторів: композитора і поета.

Контингент студентів, який навчається у музично-педагогічному закладі відрізняється органічними голосовими даними. На першому курсі навчання, студент з голосовим діапазоном, який має одну, а то й менше октаву, малу силу звуку явище нерідке. Безперечно, всі ці голоси, в тому числі і такі в процесі навчання розвиваються, також їх діапазон. Тут виникає проблема в особливості систематизації навчального репертуару. Поступове зростання вокальнотехнічних i художніх труднощів творів приходиться здійснювати в рамках вказаних якостей, що обумовлює скорочення репертуару уподобань у навчанні в класі сольного співу. Обмеженість діапазону голосу студента створює певні труднощі при складанні творів індивідуального плану і не так просто підбирати твори для студента старшого курсу, який не може справитися 3 інтерпретацією важкого музичнохудожнього твору, бо при цьому має слабкі вокальні дані і перш за все маленький діапазон голосу. Звісно, що невеликий діапазон голосу створює певну проблему у підборі вокальних творів. У подальшій роботі розвитку діапазону голосу необхідно навчити студента правильно формувати перехідні ноти у верхньому регістрі голосу. Звісно, ця справа непроста і потребує часу та належного і тонкого підходу для створення правильного режиму роботи механізму вокального апарату. Коли студент опанує формування перехідних нот, це дає можливість розширити його діапазон голосу i значно урізноманітнили репертуар, покращити вокальнотехнічні дані.

Учні вступають у вуз з достатньо високою музичною підготовкою. У них добре розвинуті музичні і в певній мірі художні здібності в процесі інструментального навчання. В той же час у більшості з них не має ніякого вокального досвіду, лише у випадках у випускників училищ диригентсько-хормейстерської спеціальності вокальна підготовка, як правило набагато вища загальноосвітньої. Таким чином, із-за цього розриву між вокально-технічним і загальномузичним рівнем студента ускладнюється підбір творів у відносності для кожного студента. При підборі і застосуванні навчального матеріалу в класі вокалу проявляється професійна направленість підготовки студента. В індивідуальному плані студентів значне місце займає матеріал шкільного спрямування, який нами, викладачами вокалу розглядається досить широко, це не тільки вокалізи, народні пісні, твори класиків, в програмний матеріал в обов'язковому порядку включаються твори шкільного репертуару, які заплановані посеместрово на всіх курсах стаціонарної та заочної форм навчання. Професійна спрямованість проявляється у виконанні шкільних пісень. Студент навчається не тільки художньо і технічно правильного виконувати, але й методично вміти аналізувати вокально-технічну сторону. На основі цього аналізу виникають основні педагогічні завдання, які допомагають подоланню їх труднощів.

Таким чином, навчальний матеріал при навчанні в класі вокалу повинен бути не тільки основним засобом музично-естетичного, вокально-технічного виховання, але й розвивати студента методично.

Твори вокально-педагогічного художнього репертуару в основному діляться на такі жанри: 


\section{ЗНАЧЕННЯ НАВЧАЛЬНОГО МАТЕРІАЛУ \\ У ІНДИВІДУАЛЬНІЙ ВОКАЛЬНІЙ ПІДГОТОВЦІ СТУДЕНТА}

арія, романс, пісня, народна пісня. Всі ці жанри мають свої специфічні особливості і по різному впливають на формування голосу студента в процесі його навчання.

Арія - це найбільш складна вокальна форма. Вона входить в склад до великого вокальносимфонічного твору і являє собою закінчений епізод, який може виконуватися зовсім самостійно. Співак - виконавець арії повинен вміти створити образ героя, зберегти при цьому всі деталі, штрихи, витримувати всю драматичну ситуацію твору. Ці вимоги поширюються і на інші сольні жанри оперної літератури, виконуючи функції арії, як наприклад, арієтта, аріозо, каватина. Арії у великій ступені, як і інші вокальні жанри, сприяють розвитку вокально-виконавської сторони навчання і також вокально-технічним прийомам співу. На початковому етапі навчання, як правило, потрібно по можливості не планувати арії в навчальний матеріал [4, 53 - 57].

Романс - це найбільш розвинута вокальнопісенна форма. У розвитку і формуванні співака романс відіграє велику роль, який розвиває у співака специфічні прийоми в камерному стилі виконання. Романс слід розцінювати як синтез трьох видів мистецтва поезії, пісні та інструментальної музики, що органічно пов' язані між собою.

Романс потребує від співака належної музичнохудожньої і вокально-технічної підготовки. Особливо це стосується романсів Д. Січинського, П. Чайковського, які є складні з вокально-технічної сторони, також мають складні інтонаційномелодійні звороти і тонкі рисунки художньовиразного співу і потребують високої виконавської майстерності. Тому викладачеві не варто на початку навчання включати в репертуар складні твори цього жанру.

Пісня являє собою найбільш демократичний розповсюджений і масовий жанр вокальної літератури. Вона, як романс і арія сприяє розвитку у співака музично-виконавських навиків. $С$ багато пісень: героїчного, драматичного i ліричного характеру, які $є$ корисним педагогічним матеріалом для виховання співака початківця $\mathrm{i}$ його розвитку голосу. В індивідуальний план початківця-співака, як основу основ включається вивчення української народної пісні.

Робота проводиться за ведучим принципом музичної педагогіки: єдністю вокально-технічної і художньої сторін навчання. Пісенна творчість українського народу, що складалася i збагачувалась протягом століть є справжнім золотим фондом української музичної культури, усним літописом життя нашої Батьківщини, бо народні пісні - це народна історія, жива, яскрава, сповнена барв істини, історія, яка розкриває все життя іiї народу. Народна пісня виникла в глибокій давнині. Вона почала розвиватися разом 3 трудовими процесами і людським мисленням, відображаючи життя, побут і світогляд наших предків - східних слов'ян ще у докласовому суспільстві. Музична мова, мелодика народних пісень - високо поетичні і виразні. В них немає нічого зайвого, незначного, беззмістовного. Мелодії кращих українських народних пісень $\epsilon$ наслідком послідовного відбору, удосконалення виконання народних співців, вживання найбільш виразних типових мелодійних зворотів та інтонацій $[5,69-70]$.

Від народної пісенної творчості від народженого виконавства народилася i формувалася та парость вокального мистецтва, яка нині називається європейською манерою оперно-концертного співу. Все найцінніше в цьому мистецтві (і в музиці взагалі) пішло і йде від народної основи. Красива вокальна лінія мелодії народної пісні дає можливість студенту розвинути вокально-технічні навики, допомагає формувати правильне звукоутворення голосних, виробляючи плинність, кантилену голосу (belcanto) на рівні співучої італійської мови.

Різножанрова народна пісня, яка має глибокий зміст поетичного слова перевтілює виконавця в різний психологічно-виконавський стан, виховуючи і збагачуючи його духовно-емоційні якості.

Вокально-музичне - виховання студента перш за все повинно базуватися на національній основі. Народна пісня має стати основним навчальним матеріалом до кінця навчання студента.

Українська народна пісня втілена великими українськими та російськими класиками, як оперних так і в окремих симфонічних творах.

Наприклад, в опері “Сорочинський ярмарок” Мусорського звучить український гопак. Українські пісні обробляли М. Глінка, П. Чайковський, А. Римський-Корсаков, теж і колядки в "Ніч перед Різдвом”, вже не кажучи про А. ГулакаАртемовського, М. Лисенка.

У вокально-музичному вихованні студента народна пісня повинна бути домінуючою i вирішальною у формуванні правильних ідейноестетичних і вокально-технічних навиків, які дозволяють в майбутньому розкрити і оцінити красу і багатство як своєї народної і професійної музики, так і творів світової музичної культури. Роль народної пісні в системі музичного виховання і освіти важко переоцінити, адже вона як один із видів художнього надбання народу 
багатогранно відображає життя людини в різні суспільно-історичні епохи, розкриває ії духовне багатство, красу, морально-етичні ідеали, тяжіння до добра і справедливості.

Стикаючись 3 народними піснями різних жанрів, студенти глибше пізнають світ, знайомляться з історією і звичаями рідного народу. Вони збагачують свою уяву яскравими музичнопоетичними образами, що викристалізовувались протягом багатьох сторіч у процесі колективної творчої практики різних поколінь. В кожній народній пісні закономірно просліджується своєрідний шлях емоційного пізнання i сприймання життя наших предків 3 допомогою здавна існуючих різноманітних музичних форм $\mathrm{i}$ жанрів, що може бути ефективним музичновиховним матеріалом. Отже, народна пісня служить могутнім засобом не лише для пізнання минулого, але й для виховання сучасної молоді.

Народна пісня є відображенням національної культури, що своїм корінням глибоко сягає в товщу народного життя, несе в собі велику виховну силу. В ній проявляється характер, особливості душі народу, виражається любов до рідного краю, Батьківщини. В народній пісні поєднуються сердечність і ласка, гумор і жарт.

Залучення народної пісні до духовних багатств (звичаїв, ритуалів, моральних норм, традицій, народної мудрості) на всіх етапах розвитку людства стало складовою частиною загального виховання підростаючого покоління. Тому учитель музики та співів має вміти фахово розкрити перед учнями всю велич і красу української пісні, одного з найбільших багатств нашого народу.

Висновки. Якісна підготовка фахівців, яка відповідає запитам сьогодення пов'язується 3 вокально-технічною та методичною підготовкою студента, його швидкою адаптацією роботи у загальноосвітній школі. Вдало підібраний репертуар вокальних творів сприятиме вокальному розвитку та подальшій музичній підготовці фахівців.

\section{ЛІТЕРАТУРА}

1. Вилинськая Н. Вопросы вокальной педагогики / Н. Вилинськая. - Москва: - Музыка, 1967. - 149 с.

2. Голубев П. Педагог-вокалист /П. Голубев. К.: Музична Україна, 1980. - 73 с.

3. Свтушенко Д. Роздуми про голос / Д. Свтушенко. - К.: Музична Україна, 1979. - 89 с.

4. Михайлова Т. Вопросы вокальной педагогики /Т. Михайлова. - Москва: - Музыка, 1967. - $149 \mathrm{c}$.

5. Народна пісня та відродження іiї в учбововиховний процес в умовах відродження національної культури: Матеріали республіканської науковопрактичної конференції. - Ніжин, 1991. - 93 с.

\section{REFERENCES}

1. Vilinskaya, N. (1967). Voprosy vokalnoy pedagogiki [The questions of vocal pedagogy]. Moscov: Muzyka, 149 p. [in Russian].

2. Golubev, P. (1980). Pedagog-vokalist [A vocalist teacher]. Kyiv: Muzichna Ukraina, 73 p. [in Russian].

3. Ievtushenko, D. (1979). Rozdumy pro holos [Reflections by the voice]. Kyiv: Muzychna Ukraina, 89 p. [ in Ukrainian].

4. Mikhaylova, T. (1967). Voprosy vokalnoy pedagogiki [The questions of vocal pedagogy]. Moscov: Muzyka, 149 p. [in Russian].

5. Narodna pisnia ta vidrodzhennia yii v uchbovovykhovnyi protses $\mathrm{v}$ umovakh vidrodzhennia natsionalnoi kultury: Materialy respublikanskoi naukovo-praktychnoi konferentsii - The folk song and its revival in the educational process in the conditions of the revival of national culture: Proceedings of the Republican Scientific and Practical Conference (93p.). Nizhyn, 1991. [in Ukrainian].

Стаття надійшла до редакції 27.02.2018

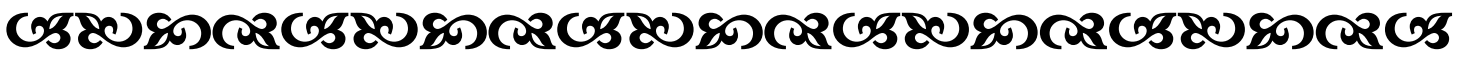

“Дюбов і робота є наріжними қаменями нашої людяності".

\author{
Зигмунд Фрейд \\ австрійський психолог
}

“Едина розкіш, яқу я знаю, - розқіш людського спілқування”.

Антуан де Сент-Еқзюорері франиузький письменник.

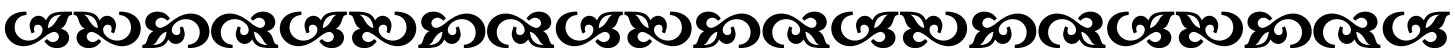

